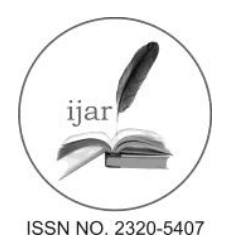

\section{Journal homepage:http://www.journalijar.com \\ Journal DOI:10.21474/IJAR01}

\section{RESEARCH ARTICLE}

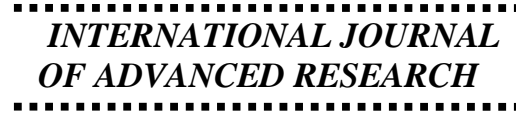

-

\title{
A study on milk producing farmer's perception towards komul with special reference to kolardist,
} Karnataka.

\section{"R. Kiran Reddy ${ }^{1}$ and Dr. R. Vara Prasad ${ }^{2}$.}

1. Student, Department of Management Studies, Madanapalle Institute of Technology and Science, Madanapalle.

2. Assistant Professor, Department of Management Studies, Madanapalle Institute of Technology and Science, Madanapalle.

\section{Manuscript Info}

\section{Manuscript History:}

Received: 15 May 2016

Final Accepted: 16 June 2016

Published Online: July 2016

Key words:

Milk Producing farmers,

cooperative societies, KOMUL

*Corresponding Author

\section{R. Kiran Reddy.}

\section{Abstract}

The paper makes an attempt to examine the milk producer'sperception towards Kolar Dist. Cooperative Milk Producer's Societies Union Ltd., (KOMUL) with the help of an empirical study conducted in three selected taluks of Kolar district of Karnataka. The findings clearly show that the production of milk varies from age, experience and education. The present study also identified the services rendered by KOMUL on disseminating modern technology and knowledge among its members through regular training, extension services, method demonstrations, field trials, provision of animal health care facilities, free supply of fodder. As a result the knowledge level of farmers connected with cooperative society differs to a great extent from that of the non-members.

Copy Right, IJAR, 2016,. All rights reserved.

\section{Introduction:-}

Dairy sector plays an important role in India's socio-economic development, and constitutes an important segment of the rural economy. Dairy industry provides livelihood to millions of homes in villages, ensuring supply of quality milk and milk products to people in both urban and rural areas. Indian dairy industry has been growing rapidly keeping pace with increase in milk consumption. This sector also plays significant role in supplementing family incomes and generating gainful employment in the rural sector, particularly among the landless laborers, small and marginal farmers and women, besides providing nutritional food to millions of people at equitable price.

India with 204 million cows and 84 million buffaloes has the largest population of cattle in the world. Milk production gives employment to 70 million dairy farmers. In terms of total production, India ranks first with a production of 78 million tons annually. Besides, it is one of the largest producer as well as consumer of dairy products. Due to their rich nutritional qualities, the consumption of dairy products has been growing exponentially in the country.

Though India is the largest milk producer in the world no Indian dairy made it to the top twenty, because of highly unorganized nature of the Indian dairy industry and also because it is driven by cooperatives and not companies. Indian organized dairy industry is largely, packed milk market. Packed milk captures two-third of the organized dairy market in India. Whereas value-added products accounts for one-fifth of the organized dairy market in India. "This trend is epitomized by most of the leading dairy players in India. This is the reason for low realization per liter of milk handled by organized players in India. However, we see a trend of shift towards value-added products which will be 30 per cent of the organized dairy market in next five years. This will help improve the realization and the margins for the dairy players." 
It is evident from the statistics that the dairy industry is playing an important role in providing employment to millions of people in India leading us to focus on understanding the various problems faced by the milk producing farmer and for this purpose farmers who are actively engaged in supplying milk to KOMUL would be the best source of information who can reflect the overall population across south India.

\section{Need for the study:-}

India is one of the world's largest milk producer and consumer. Dairy industry in Indiais the second largest employment provider, helping the rural hose hold to earn their daily bread. Majority of the Indian milk producing farmers take up milk production parallel to the main stream agriculture. Farmers in rural India are limited to formal education and experience lot of challenges to achieve excellence in milk farming where as their counterparts in the western nations have access to education and technology help.

This present paper provides an insight to understand the various challenges the milk producing farmers are going through and the feasibility measures taken by the KOMUL co-operative milk society.

\section{Objectives of the study:-}

* To study the impact of milk producing farmersdemographic factors on their milk production.

* To study the various services rendered by KOMUL dairy towards milk producing farmers.

* To analyze the satisfaction level of milk producing farmers towards KOMUL dairy.

\section{Hypotheses:-}

* H1: There is no significant relationship between the milk producing farmer gender with respect to quantity of milk produced.

* H2: There is no significant relationship between the milk producing farmer age with respect to quantity of milk produced.

* H3: There is no significant relationship between the milk producing farmer education with respect to quantity of milk produced.

* H4: There is no significant difference between the satisfaction levels of milk producing farmers with respect to KOMUL dairy.

* H5: There is a significant relation between the subsidy and quality of feed provided by KOMUL.

\section{Review of Literature:-}

D. S. Thakur's, (1975), Analysis on progress of milk societies, milk unions and the impact of milk co-operatives on the economic conditions of rural people including the weaker sections in the Gujarat was remarkable in terms of increasing number of milk societies; total membership, share 30 capital, reserve fund, net profit, milk collected and transactions were made since their inception.

Researcher also indicated the impact of technical inputs disbursed by milk co-operatives on production and marketed surplus of milk, adoption of improved agricultural inputs and the annual income of the milk producers.

Milk production per animal and marketed surplus is a little higher in the experimental villages than in the control villages. In experimental villages, the use of improved agricultural input and total incomes are found to be higher. The marketed surplus of milk is higher in the case of the weaker sections compared to the medium and large farmers in general seems to be too obvious a conclusion.

Singh, K. and Das. V. M. (1980), they conducted a study on impact of operational flood at the village level and found that the proportion of animals in milk to total milk animals was higher in the co-operative villages than in the control villages. The average household income from all sources was substantially higher in the co-operative villages than non-operative villages; however, the distribution of income from milk did not show any trend. The study further observed that the average employment of family labour in milk production was marketed higher in the co-operative villages than in the control villages. The awareness of scientific animal health care and improved feeding practices of respondents of co-operative village are more than control villages

Kherde, R. L. and Subramaniom, R. (1980), Studied the impact of milk marketing through dairy co-operatives and found significant increase in the milk production in the co-operative villages whereas there was decline in the duration of age at first calving, calving interval, dry period and mortality rate in buffaloes. The net income of the 
milk producers increased under co-operative villages probably due to efficient and assured milk marketing through co-operatives. Employment days generated per farm in co-operative villages were more than non-co-operative villages.

Singh, M. et al. (1985), conducted a study on operational efficiency of U.P. milk co-operatives and found that the services like veterinary aid, cattle feed and marketing facilities were insufficient. Input services like artificial insemination (AI), pregnancy diagnosis, balance cattle feed and vaccination against communicable disease have appositive bearing on the efficiency of milk cooperatives. And concluded that the communication system should be made strong for quick transmission of latest technology, technical know-how pertaining to dairy as well as input services should be strengthened in the state to attain desired efficiency of milk co-operative societies

K. Rajendran and SamarenduMohanty (2004) "Dairy Co-operatives and Milk Marketing in India: Constraints and Opportunities", in this study it is pointed out that the Operation Flood and dairy co-operatives emerged in India as the largest rural employment scheme, enabling the modernization of the dairy sector to a level from where it can take off to meet not only the country's demand for milk and milk products but can also exploit global market opportunities. This study reviews the existing status of milk marketing and dairy co-operatives in India and provides recommendations to meet future challenges.

The results of the study indicate that 80 percent of the milk produced by the rural producer is handled by an unorganized sector and the remaining 20 percent is handled by an organized sector. It is found that the dairy cooperatives play a vital role in alleviating rural poverty by augmenting rural milk production and marketing. Involvement of intermediaries; lack of bargaining power by the producers; and lack of infrastructure facilities for collection, storage, transportation, and processing are the major constraints which affect the prices received by producers in milk marketing. Milk quality, product development, infrastructure support development, and global marketing are found to be future challenges of India's milk marketing.

R B; Dayal, Rekha (2004) "Economic Analysis of Production and Marketing of Milk in Central Region of Uttar Pradesh" The study examines the economics of production and marketing of milk in the state of Uttar Pradesh. Linear and log-linear functions were used to work out the estimates of factors affecting marketed surplus of milk both for the private and cooperative systems. The results of the study indicate that the feed and fodder cost was the most important item of the total maintenance cost accounting for 55 to 65 per cent of the total cost in Zone I and 51 to 66 per cent in Zone II. The net profit per day of a milch buffalo was very low due to the higher maintenance cost

Varaprasad, R., \& Rao, K. V. (2014) Consumer Perception and Satisfaction with Branded Milk and Milk Products. This study examines the brand awareness of branded milk and milk products and consumers reasons for preferring a particular brand. As majority of the branded milk are produced by either private companies or cooperative societies, this study has resulted in customer's preference towards cooperative societies branded milk.

\title{
Sources of data:- \\ Primary data:-
}

Primary data has been collected from 150 milk producing farmers fromthree selected taluks (Mulbagal, Bangarpet and Kolar) of Kolar District using convenience sampling method.

\section{Secondary data:-}

Secondary Data was collected through various websites, Journals, Books etc.

\section{Sample design:}

1. Sampling Frame: Those who sell milk to different co-operative societies in Kolar District.

2. Sampling Unit: Producers who sell milk to KOMUL (3 Taluks) from each taluk 150 members.

3. Sample size: 450

4. Sampling Method: Convenience sampling

\author{
Statistical tools used:- \\ * SPSS 20 has been used to draw the results. \\ * Chi-square method was adopted to draw inferences based on the questionnaire. \\ * ANOVA technique was used to analyze the data.
}


* Descriptive statistics technique was used to analyze the data.

Scope of the study:-

* The present study is undertaken in the Kolar district of Karnataka. The geographical area of this district is surrounded with agricultural farms and hills. The major occupation of the people of this district is agriculture. The present study has analyzed the perception of milk producing farmers in this district.

* The present study is undertaken in the three taluks of Kolar district of Karnataka. In each taluk 150 samples are collected from the milk producing farmers to know their perception towards KOMUL.

\section{Limitations of the study:-}

The following are the limitations of the study

* The study is confined only to Kolar district of Karnataka.

* Time limit was one of the main constraints.

* It was assumed that the information provided by respondents are true in nature.

Data Analysis and Interpretation:-

Table - 1:-Gender

\begin{tabular}{|l|l|l|l|l|l|}
\hline \multicolumn{2}{|c|}{} & Frequency & Percent & Valid Percent & Cumulative Percent \\
\hline \multirow{3}{*}{ Valid } & MALE & 375 & 83.3 & 83.3 & 83.3 \\
\cline { 2 - 6 } & FEMALE & 75 & 16.7 & 16.7 & 100.0 \\
\cline { 2 - 6 } & Total & 450 & 100.0 & 100.0 & \\
\hline
\end{tabular}

Source: Field Survey

Inference: It can be seen from the above table that, an overwhelming majority of 83.3 percent of the respondents are male and only 16.7 percent of the respondents are female.

Table - 2:-AGE

\begin{tabular}{|l|l|l|l|l|l|}
\hline \multicolumn{2}{|l|}{ Age } & Frequency & Percent & Valid Percent & Cumulative Percent \\
\hline \multirow{3}{*}{ Valid } & $20-39$ YEARS & 102 & 22.7 & 22.7 & 22.7 \\
\cline { 2 - 6 } & 40-59 YEARS & 254 & 56.4 & 56.4 & 79.1 \\
\cline { 2 - 6 } & $60-79$ YESARS & 93 & 20.7 & 20.7 & 99.8 \\
\cline { 2 - 6 } & ABOVE & 1 & .2 & .2 & 100.0 \\
\cline { 2 - 6 } & YEARS & & & & \\
\cline { 2 - 6 } & Total & 450 & 100.0 & 100.0 & \\
\hline
\end{tabular}

Source: Field Survey

Inference: It can be examined from the above table that, a majority (56.4percent) of the respondents are in the age group of 40 to 59 years, followed by 22.7 percent are in the age group of 20 to 39 years, 20.7 percent of the respondents are in the age group of 60 to 79 years. Whereas 0.2 per cent of the respondents are above 80 years of age.

Table - 3:-Education

\begin{tabular}{|l|l|l|l|l|l|}
\hline \multicolumn{2}{|c|}{} & Frequency & Percent & Valid Percent & Cumulative Percent \\
\hline \multirow{6}{*}{ Valid } & SSC & 130 & 28.9 & 28.9 & 28.9 \\
\cline { 2 - 5 } & Secondary education & 158 & 35.1 & 35.1 & 64.0 \\
\cline { 2 - 5 } & UG & 34 & 7.6 & 7.6 & 71.6 \\
\cline { 2 - 5 } & PG & 1 & .2 & .2 & 71.8 \\
\cline { 2 - 5 } & Illiterate & 127 & 28.2 & 28.2 & 100.0 \\
\cline { 2 - 5 } & Total & 450 & 100.0 & 100.0 & \\
\hline
\end{tabular}

Source: Field Survey

Inference: It can be interpreted from the above table that, a majority of the respondents (35.1 percent) are having Secondary Education, followed by 28.9 percent with SSC qualification followed by illiterates with 28.2 per cent and as many as $7.6 \%$ are Under-graduates. 
Table - 4:- Marital Status

\begin{tabular}{|l|l|l|l|l|l|}
\hline \multicolumn{2}{|c|}{} & Frequency & Percent & Valid Percent & Cumulative Percent \\
\hline \multirow{2}{*}{$\begin{array}{l}\text { Vali } \\
\text { d }\end{array}$} & MARRIED & 422 & 93.8 & 93.8 & 93.8 \\
\cline { 2 - 5 } & UN MARRIED & 28 & 6.2 & 6.2 & 100.0 \\
\cline { 2 - 5 } & Total & 450 & 100.0 & 100.0 & \\
\hline
\end{tabular}

Source: Field Survey

Inference: It can be interpreted from the above table that, a majority of the respondents $93.8 \%$ are married and $6.2 \%$ of the respondents are unmarried.

Table - 5:-How many number of milking cattle do you own

\begin{tabular}{|l|l|l|l|l|l|}
\hline \multicolumn{2}{|c|}{} & Frequency & Percent & Valid Percent & Cumulative Percent \\
\hline Valid & up to 2 & 211 & 46.9 & 46.9 & 46.9 \\
\cline { 2 - 5 } & $3-5$ & 185 & 41.1 & 41.1 & 88.0 \\
\cline { 2 - 5 } & above 5 & 54 & 12.0 & 12.0 & 100.0 \\
\cline { 2 - 5 } & Total & 450 & 100.0 & 100.0 & \\
\hline
\end{tabular}

Source: Field Survey

Inference: It can be interpreted from the above table that $46.9 \%$ of the respondents are having 1 to 2 milking cattle, where as $41.1 \%$ are having 3-5 milking cattle and only $12.0 \%$ are having above 5 milking cattle.

Table - 6:-Number of Liters of milk procured per day

\begin{tabular}{|l|l|l|l|l|l|}
\hline \multicolumn{2}{|c|}{} & Frequency & Percent & Valid Percent & Cumulative Percent \\
\hline Valid & Less than5liters & 88 & 19.5 & 19.5 & 19.5 \\
\cline { 2 - 6 } & 5 to 10liters & 160 & 35.4 & 35.4 & 54.9 \\
\cline { 2 - 6 } & 10 to 15liters & 120 & 26.5 & 26.5 & 81.4 \\
\cline { 2 - 6 } & 15 to 20liters & 84 & 18.6 & 18.6 & 100.0 \\
\cline { 2 - 6 } & Total & 452 & 100.0 & 100.0 & \\
\hline
\end{tabular}

Source: Field Survey

Inference: It can be interpreted from the above table that $35.4 \%$ cattle is producing 5 to 10 liters, $26.5 \%$ cattle is producing 10 to 15 liters where as $19.5 \%$ cattle is producing less than 5 liters.

Table - 7:- Feed required per day

How much feed do your cows require per day

\begin{tabular}{|c|c|c|c|c|c|}
\hline & & Frequency & Percent & Valid Percent & Cumulative Percent \\
\hline \multirow[t]{5}{*}{ Valid } & $2 \mathrm{~kg}$ & 37 & 8.2 & 8.2 & 8.2 \\
\hline & $4 \mathrm{~kg}$ & 108 & 24.0 & 24.0 & 32.2 \\
\hline & $6 \mathrm{~kg}$ & 96 & 21.3 & 21.3 & 53.6 \\
\hline & above $6 \mathrm{~kg}$ & 209 & 46.4 & 46.4 & 100.0 \\
\hline & Total & 450 & 100.0 & 100.0 & \\
\hline
\end{tabular}

Inference: The above table details about the feed required for a day, $8.2 \%$ need $2 \mathrm{~kg}$ per day, $24 \%$ need $4 \mathrm{~kg}$ per day, $21.3 \%$ need $6 \mathrm{~kg}$ per day and $46.4 \%$ are need above $6 \mathrm{~kg}$ per day.

Is KOMUL supplying feed?

Table - 8:-Supplying feed by KOMUL

\begin{tabular}{|l|l|l|l|l|l|}
\hline \multicolumn{2}{|c|}{} & Frequency & Percent & Valid Percent & Cumulative Percent \\
\hline Valid & Yes & 441 & 98.0 & 98.0 & 98.0 \\
\cline { 2 - 6 } & No & 9 & 2.0 & 2.0 & 100.0 \\
\cline { 2 - 6 } & Total & 450 & 100.0 & 100.0 & \\
\hline
\end{tabular}

Inference: The above table infers that $98 \%$ of respondents said KOMUL is supplying feed and remaining $2 \%$ said they will not supply feed. 
Table - 9:- Subsidy provided by KOMUL

'Yes', what is the \% of subsidy KOMUL is providing?

\begin{tabular}{|l|l|l|l|l|l|}
\hline \multicolumn{2}{|c|}{} & Frequency & Percent & Valid Percent & Cumulative Percent \\
\hline Valid & N/A & 298 & 66.2 & 66.2 & 66.2 \\
\cline { 2 - 6 } & $20 \%$ & 29 & 6.4 & 6.4 & 72.7 \\
\cline { 2 - 6 } & $5 \%$ & 123 & 27.3 & 27.3 & 100.0 \\
\cline { 2 - 6 } & Total & 450 & 100.0 & 100.0 & \\
\hline
\end{tabular}

Inference: It is inferred from the above table that $66.2 \%$ are not aware of subsidy, $6.4 \%$ of the respondents said that they are receiving $20 \%$ subsidy and $27.3 \%$ responded that only $5 \%$ subsidy is provided.

Table - 10:-Satisfied with subsidy and quality of feed

Are you satisfied with the subsidy and quality of feedprovided by KOMUL?

\begin{tabular}{|l|l|l|l|l|l|}
\hline \multicolumn{2}{|l|}{} & Frequency & Percent & Valid Percent & Cumulative Percent \\
\hline Valid & Yes & 353 & 78.4 & 78.4 & 78.4 \\
\cline { 2 - 6 } & No & 97 & 21.6 & 21.6 & 100.0 \\
\cline { 2 - 6 } & Total & 450 & 100.0 & 100.0 & \\
\hline
\end{tabular}

Inference: The above table indicates that $78.4 \%$ are satisfied with the subsidy whereas 21.6 not satisfied with the subsidy provided.

Table - 11:-Veterinary services provided by KOMUL

Is KOMUL providing veterinary services?

\begin{tabular}{|l|l|l|l|l|l|}
\hline \multicolumn{2}{|l|}{} & Frequency & Percent & Valid Percent & Cumulative Percent \\
\hline Valid & Yes & 450 & 100.0 & 100.0 & 100.0 \\
\hline
\end{tabular}

Inference: $100 \%$ of respondents said that KOMUL is providing veterinary services.

Table - 12:- How many times does KOMUL provide veterinary services in a year

If 'YES', how many times in a year

\begin{tabular}{|c|c|c|c|c|c|}
\hline & & Frequency & Percent & Valid Percent & Cumulative Percent \\
\hline \multirow[t]{6}{*}{ Valid } & $<3$ times & 60 & 13.3 & 13.3 & 13.3 \\
\hline & 3-6 times & 99 & 22.0 & 22.0 & 35.3 \\
\hline & $6-9$ times & 11 & 2.4 & 2.4 & 37.8 \\
\hline & every month & 3 & .7 & .7 & 38.4 \\
\hline & Based on necessity & 277 & 61.6 & 61.6 & 100.0 \\
\hline & Total & 450 & 100.0 & 100.0 & \\
\hline
\end{tabular}

Inference: $13.3 \%$ responded that 3 times in a year, $22 \%$ responded that 3-6 times in a year, 2.4\% responded that 6-9 times in a year, $0.7 \%$ responded that every month they will receive services and 61.6 responded that based on necessity they will receive veterinary services.

Table - 13:- Training programs provided by KOMUL

Is KOMUL providing training programs?

\begin{tabular}{|l|l|l|l|l|l|}
\hline \multicolumn{2}{|l|}{} & Frequency & Percent & Valid Percent & Cumulative Percent \\
\hline \multirow{3}{*}{ Valid } & Yes & 166 & 36.9 & 36.9 & 36.9 \\
\cline { 2 - 6 } & No & 284 & 63.1 & 63.1 & 100.0 \\
\cline { 2 - 6 } & Total & 450 & 100.0 & 100.0 & \\
\hline
\end{tabular}

Inference:From the above table it is inferred that $36.9 \%$ said that training programs are providedwhereas $63.1 \%$ responded that training programs are not provided by KOMUL.

Table - 14:- Training programs are really helpful

If 'YES' are the training programs really helpful in increasing the productivity

\begin{tabular}{|l|l|l|l|l|l|}
\hline \multicolumn{2}{|c|}{} & Frequency & Percent & Valid Percent & Cumulative Percent \\
\hline Valid & N/A & 284 & 63.1 & 63.1 & 63.1 \\
\cline { 2 - 6 } & Yes & 164 & 36.4 & 36.4 & 99.6 \\
\cline { 2 - 6 } & No & 2 & .4 & .4 & 100.0 \\
\cline { 2 - 6 } & Total & 450 & 100.0 & 100.0 & \\
\hline
\end{tabular}


Inference: From the above table it is inferred that $63.1 \%$ said N/A, $36.4 \%$ said it is helpful in improving productivity and only $0.4 \%$ said it is not helpful for productivity.

Table - 15:- Insurance to your Cow/Buffalo

Do you have insurance to your cow/Buffalo?

\begin{tabular}{|l|l|l|l|l|l|}
\hline \multicolumn{2}{|l|}{} & Frequency & Percent & Valid Percent & Cumulative Percent \\
\hline \multirow{3}{*}{ Valid } & Yes & 140 & 31.1 & 31.1 & 31.1 \\
\cline { 2 - 6 } & No & 310 & 68.9 & 68.9 & 100.0 \\
\cline { 2 - 6 } & Total & 450 & 100.0 & 100.0 & \\
\hline
\end{tabular}

Inference: From the above table it is inferred that $31.1 \%$ have insured their cow/buffalo and $68.9 \%$ have not insured their cow/buffalo.

Table -16:- Insurance services provided by KOMUL

If 'YES', KOMUL is providing any insurance services?

\begin{tabular}{|l|l|l|l|l|l|}
\hline \multicolumn{2}{|c|}{} & Frequency & Percent & Valid Percent & Cumulative Percent \\
\hline Valid & N/A & 310 & 68.9 & 68.9 & 68.9 \\
\cline { 2 - 6 } & Yes & 122 & 27.1 & 27.1 & 96.0 \\
\cline { 2 - 6 } & No & 18 & 4.0 & 4.0 & 100.0 \\
\cline { 2 - 6 } & Total & 450 & 100.0 & 100.0 & \\
\hline
\end{tabular}

Inference: The above table denotes that $68.9 \%$ said N/A, $27.1 \%$ said yes and $4 \%$ saidNO.

Table - 17:- Dairy equipment's provided by KOMUL

Is KOMUL providing any dairy equipment?

\begin{tabular}{|l|l|l|l|l|l|}
\hline \multicolumn{2}{|c|}{} & Frequency & Percent & Valid Percent & Cumulative Percent \\
\hline Valid & Yes & 151 & 33.6 & 33.6 & 33.6 \\
\cline { 2 - 6 } & No & 299 & 66.4 & 66.4 & 100.0 \\
\cline { 2 - 6 } & Total & 450 & 100.0 & 100.0 & \\
\hline
\end{tabular}

Inference: The above table denotes that $33.6 \%$ have received dairy equipment and only $66.4 \%$ have not received any dairy equipment.

Table - 18:- Subsidy provided by KOMUL

If 'YES', how much percentage of subsidy KOMUL is providing to you

\begin{tabular}{|l|l|l|l|l|l|}
\hline \multicolumn{2}{|c|}{} & Frequency & Percent & Valid Percent & Cumulative Percent \\
\hline Valid & $20 \%$ & 25 & 5.6 & 5.6 & 5.6 \\
\cline { 2 - 6 } & $25 \%$ & 19 & 4.2 & 4.2 & 9.8 \\
\cline { 2 - 6 } & $50 \%$ & 105 & 23.3 & 23.3 & 33.1 \\
\cline { 2 - 6 } & N/A & 301 & 66.9 & 66.9 & 100.0 \\
\cline { 2 - 6 } & Total & 450 & 100.0 & 100.0 & \\
\hline
\end{tabular}

Inference:From the above table it is inferred that varied subsidies are provided, 5.6\% of the respondents are receiving $20 \%, 4.2 \%$ are receiving $25 \%, 23.3 \%$ are receiving $50 \%$ and $66.9 \%$ are N/A.

Table - 19:-Remuneration paidby KOMUL per Liter How much remuneration KOMUL is paying per Liter

\begin{tabular}{|c|c|c|c|c|c|}
\hline & & Frequency & Percent & Valid Percent & Cumulative Percent \\
\hline \multirow[t]{5}{*}{ Valid } & 20 & 3 & .7 & .7 & .7 \\
\hline & 22 & 385 & 85.6 & 85.6 & 86.2 \\
\hline & 24 & 3 & .7 & .7 & 86.9 \\
\hline & 26 & 59 & 13.1 & 13.1 & 100.0 \\
\hline & Total & 450 & 100.0 & 100.0 & \\
\hline
\end{tabular}

Inference:The above table denotes that, $0.7 \%$ are paid Rs. 20 per liter, $85.6 \%$ are paid Rs. 22 per liter, $0.7 \%$ are paid Rs. 24 per liter and $13.1 \%$ are paid Rs. 26 per liter. 
Table - 20:- Satisfied with KOMUL's remuneration

Are you satisfied with KOMUL's remuneration?

\begin{tabular}{|l|l|l|l|l|l|}
\hline \multicolumn{2}{|c|}{} & Frequency & Percent & Valid Percent & Cumulative Percent \\
\hline Valid & Yes & 301 & 66.9 & 66.9 & 66.9 \\
\cline { 2 - 6 } & No & 149 & 33.1 & 33.1 & 100.0 \\
\cline { 2 - 6 } & Total & 450 & 100.0 & 100.0 & \\
\hline
\end{tabular}

Inference: The above table indicates that only $6.9 \%$ are satisfied whereas $33.1 \%$ are not satisfied.

Table - 21:- Satisfied with the overall services provided by the KOMUL

Are you satisfied with the overall services provided by the KOMUL?

\begin{tabular}{|l|l|l|l|l|l|}
\hline \multicolumn{2}{|c|}{} & Frequency & Percent & Valid Percent & Cumulative Percent \\
\hline \multirow{3}{*}{ Valid } & Yes & 372 & 82.7 & 82.7 & 82.7 \\
\cline { 2 - 6 } & No & 78 & 17.3 & 17.3 & 100.0 \\
\cline { 2 - 6 } & Total & 450 & 100.0 & 100.0 & \\
\hline
\end{tabular}

Inference:The above table helps us to understand that $82.7 \%$ respondents are satisfied whereas only $17.3 \%$ are not satisfied with the services provided by KOMUL.

Table - 22:- Loans provided by KOMUL to purchase milk producing cows

Is KOMUL providing loans to purchase milk producing cows?

\begin{tabular}{|l|l|l|l|l|l|}
\hline \multicolumn{2}{|c|}{} & Frequency & Percent & Valid Percent & Cumulative Percent \\
\hline Valid & Yes & 164 & 36.4 & 36.4 & 36.4 \\
\cline { 2 - 6 } & No & 286 & 63.6 & 63.6 & 100.0 \\
\cline { 2 - 6 } & Total & 450 & 100.0 & 100.0 & \\
\hline
\end{tabular}

Inference: From the above table it is inferred that $36.4 \%$ of the farmers are receiving loans whereas $63.6 \%$ respondents said that they have not receiving any loan from KOMUL

Hypothesis Test:

H0: There is no relationship between the milk producing farmer's gender with respect to quantity of milk produced.

H1: There is relationship between the milk producing farmer's gender with respect toquantity of milk produced.

Table - 23:- Gender * Number of Liters Cross tabulation

Gender *1. No.of liters produced per day: Crosstabulation

\begin{tabular}{|l|l|l|l|l|l|l|}
\hline \multirow{2}{*}{ Count } & \multicolumn{2}{l|}{ No.of liters produced per day: } & \multirow{2}{*}{ Total } \\
\cline { 3 - 7 } \multicolumn{2}{c|}{} & $<5$ liters & $5-10$ liters & $10-15$ liters & $>15$ liters & \\
\hline \multirow{2}{*}{ Gender } & MALE & 80 & 126 & 102 & 67 & 375 \\
\cline { 2 - 7 } & FEMALE & 8 & 33 & 17 & 17 & 75 \\
\hline Total & 88 & 159 & 84 & 450 \\
\hline
\end{tabular}

Chi-Square Tests

Table 23.1:- Chi-Square Tests for Gender and No.of Liters

\begin{tabular}{|l|l|l|l|}
\hline & Value & Df & Asymp. Sig. (2-sided) \\
\hline Pearson Chi-Square & $6.807^{\mathrm{a}}$ & 3 & .078 \\
\hline Likelihood Ratio & 7.263 & 3 & .064 \\
\hline N of Valid Cases & 450 & \multicolumn{2}{l|}{} \\
\hline a. 0 cells $(0.0 \%)$ have expected count less than 5. The minimum expected count is 14.00. \\
\hline
\end{tabular}

Inference: Here the hypothesis $\mathbf{H O}$ is failed to be rejected because the p value is more than 0.05 .

H0: There is no relationship between the milk producing farmer's age with respect to quantity of milk produced.

H1: There is relationship between the milk producing farmer's age with respect to quantity of milk produced. 
Table -24:- Age * Number of Liters Cross tabulation

Age $* 1$. No.of liters produced per day: Cross tabulation

\begin{tabular}{|c|c|c|c|c|c|c|}
\hline \multirow{2}{*}{\multicolumn{2}{|c|}{ Count }} & \multicolumn{4}{|c|}{ No.of liters produced per day: } & \multirow[t]{2}{*}{ Total } \\
\hline & & $<5$ liters & 5-10 liters & 10-15 liters & $>15$ liters & \\
\hline \multirow[t]{4}{*}{ Age } & 20-39 YEARS & 11 & 33 & 30 & 28 & 102 \\
\hline & 40-59 YEARS & 41 & 92 & 72 & 49 & 254 \\
\hline & 60-79 YESARS & 35 & 34 & 17 & 7 & 93 \\
\hline & ABOVE 80 YEARS & 1 & 0 & 0 & 0 & 1 \\
\hline \multicolumn{2}{|c|}{ Total } & 88 & 159 & 119 & 84 & 450 \\
\hline
\end{tabular}

Chi-Square Tests

Table - 24.1:- Chi-Square Tests for Age and No.of Liters

\begin{tabular}{|l|l|l|l|}
\hline & Value & df & Asymp. Sig. (2-sided) \\
\hline Pearson Chi-Square & $39.020^{\mathrm{a}}$ & 9 & .000 \\
\hline Likelihood Ratio & 37.265 & 9 & .000 \\
\hline Linear-by-Linear Association & 30.112 & 1 & .000 \\
\hline N of Valid Cases & 450 & & \\
\hline a. 4 cells (25.0\%) have expected count less than 5. The minimum expected count is .19.
\end{tabular}

Inference: Here the hypothesis $\mathrm{H} 0$ is rejected because the p value is less than 0.05 .

H0: There is no relationship between the milk producing farmers education with respect to quantity of milk produced.

H1: There is relationship between the milk producing farmers and education with respect to quantity of milk produced.

Table - 25:- Educational Qualification* Number of Liters Cross tabulation

Education $* 1$. No.of liters produced per day: Cross tabulation

\begin{tabular}{|c|c|c|c|c|c|c|}
\hline \multirow{2}{*}{\multicolumn{2}{|c|}{ Count }} & \multicolumn{4}{|c|}{ No.of liters produced per day: } & \multirow[t]{2}{*}{ Total } \\
\hline & & $<5$ liters & 5-10 liters & 10-15 liters & $>15$ liters & \\
\hline & $\mathrm{SSC}$ & 26 & 46 & 32 & 26 & 130 \\
\hline & $\begin{array}{l}\text { Secondary } \\
\text { education }\end{array}$ & 21 & 57 & 49 & 31 & 158 \\
\hline & $\mathrm{UG}$ & 1 & 8 & 14 & 11 & 34 \\
\hline & PG & 0 & 1 & 0 & 0 & 1 \\
\hline & Illiterate & 40 & 47 & 24 & 16 & 127 \\
\hline Total & & 88 & 159 & 119 & 84 & 450 \\
\hline
\end{tabular}

Table - 25.1:-Educational Qualification * Number of Liters Cross tabulation

Chi-Square Tests

\begin{tabular}{|l|l|l|l|}
\hline & Value & Df & Asymp. Sig. (2-sided) \\
\hline Pearson Chi-Square & $33.594^{\mathrm{a}}$ & 12 & .001 \\
\hline Likelihood Ratio & 35.216 & 12 & .000 \\
\hline N of Valid Cases & 450 & \\
\hline a. 4 cells (20.0\%) have expected count less than 5. The minimum expected count is .19. \\
\hline
\end{tabular}

Inference: Here the hypothesis $\mathrm{H} 0$ is rejected because the p value is less than 0.05 .

ANOVA:

H0: There is no significant difference between the satisfaction levels of milk producing farmers with respect to KOMUL.

H1: There is significant difference between the satisfaction level and milk producing farmers with respect to KOMUL. 
Table - 26:- Satisfied with the overall services provided by the KOMUL

Are you satisfied with the overall services provided by the KOMUL?

\begin{tabular}{|c|c|c|c|c|c|}
\hline \multicolumn{6}{|l|}{ ANOVA } \\
\hline & Sum of Squares & Df & Mean Square & $\mathrm{F}$ & Sig. \\
\hline Between Groups & .123 & 1 & .123 & .853 & .356 \\
\hline Within Groups & 64.357 & 448 & .144 & & \\
\hline Total & 64.480 & 449 & & & \\
\hline
\end{tabular}

Inference: Here the hypothesis $\mathrm{H} 0$ is failed to be rejected because the p value is greater than 0.05 .

H0: There is significant relation between the subsidy and quality of feed provided by KOMUL.

H1: There is no significant relation between the subsidy and quality of feed provided by KOMUL.

Table -27:- ANOVA

Are you satisfied with the subsidy and quality of feed provided by KOMUL?

\begin{tabular}{|l|l|l|l|l|l|}
\hline & Sum of Squares & Df & Mean Square & F & Sig. \\
\hline Between Groups & 1.062 & 1 & 1.062 & 6.339 & .012 \\
\hline Within Groups & 75.029 & 448 & .167 & & \\
\hline Total & 76.091 & 449 & & & \\
\hline
\end{tabular}

Inference: Here the hypothesis $\mathrm{H} 0$ is failed to reject because the $\mathrm{p}$ value is greater than 0.05 .

\section{Findings:-}

1. Milk producing farmers with an age group of 40-49 are able to yield more milk compared to other age groups.

2. $28.2 \%$ of the farmers are illiterates and $28.9 \%$ of farmers have secondary school education.

3. Farmers with secondary school education are able to yield more milk.

4. The information regarding subsidies is not available with the milk producing farmers.

5. According to the survey there is a difference in services provided by KOMUL from place to place.

6. The milk producing farmers are facing problems in attending training programs conducting by KOMUL as the training programs are provided in Bangalore.

7. Most of the respondents said that the Government of Karnataka is paying a subsidy of Rs. 4 as an addition to the price paid by KOMUL (Rs. 22). Overall each farmer is paidRs. 26 (Including Rs.4+Rs.22) which has brought more satisfaction towards KOMUL.

8. In some villages there are no insurance services and in some villages there is a difference in premium.

9. Most of the milk producing farmers are satisfied with the veterinary services provided by the KOMUL.

10. There is a quality difference in feed supplying by KOMUL from place to place.

11. In some places it is found that the illiterate farmers are not aware of the insurance and the benefits from insuring their cattle.

\section{Conclusion:-}

"A study on milk producing farmer's perception towards KOMUL with special reference to Kolar District, Karnataka"is a research work envisioned to explore the impact of organized cooperative societyon improving milk producing farmer's standard of living and therefore contributing to the overall economic and regional development.

India being the world leader in milk production is embarking a volatile journey of balancing between quality and quantity of milk in contrast to world standards, in this scenario the role of cooperative societies is undeniably momentous. Though the primary objective of cooperative societies is to procure and distribute quality milk their role is extensive in reaching out to the rural and urban inhabitants stimulating to take up milk farming as core or optional employment by providing financial and materialistic support as and when needed.

It is observed that farmers with minimum education level are able to yield more milk than others, so it is suggested that apart from regular services cooperative societies should consider running evening schools for villagers as part of their CSR program. It is also observed that majority of the farmers are still adopting traditional methods of milching, an issue which need to be focused and to adopt automation changes in milk yielding process to improve quality and quantity of milching.

It is indubitable that KOMUL is successful in extending its services to the deepest villages of Karnataka. As identified through this study there are few expectations that need to be met by komul, if the cooperative societies 
across India can reach out to these milk producing farmers and address their concerns then certainly India is going to shine bright in the world of milk production.

This study will help us to understand the perception of milk producing farmers towards KOMUL one of India's best and growing cooperative society, in spite of the societies efforts to serve the milk producing farmers there are few apprehensions like subsidies, diary equipment's and fodder etc., which needs emphasis to promote milk farming.

\section{References:}

a) Acharya, R.M. (1992), Problems and prospects for dairying in India, in Growth of Indian Agriculture - Issues and Policies, Dept. of Economics and Sociology, PAU, Ludhiana.

b) Patel, R.K. (1993), "Present status and promise of dairying in India", Indian Journal of Agricultural Economics, Vol.XI.VIII, No.1, Jan-Mar.

c) No Indian dairy among world's top 20, Unorganised market, co-ops stunt local industry, August 19, 2015 Last Updated at 22:34 IST, Business Standard

d) P.T.Gangasagare and L.M.Karanjkar.(2009) They work on "Status of milk Production and economic profile of dairy farmers in the Marathwada region of Maharashtra"

e) Durgga Rani V. And Subhadra M.R. (2009) carried out research on "Training needs of farm women in dairy farming"

f) Shivakumar K. Radder and S.K. Bhanj,(2011)They work on "Perceptions of Dairy Farmers of Gadag district in northwestern part of Karnataka state, India regarding Clean Milk Production".

g) Dr R.D. Deshmukh,(2012) He work on “ Dairy farming in India”,India is a country of farming.

h) Thakur D.S. (1975), Impact of Dairy Development through milk cooperatives A case study of Gujarat. Indian Journal of Agricultural Economics Vol. XXX (3) Sept. P. 83.

i) Sing K. and Das V.M. (1980), Impact of Operational flood - I at village level, (memeo) Institute of Rural Management, Anand, Aug.P.2.

j) Kherde R.L. and Subramaniam R. (1980), "Impact of Milk Marketing through Dairy Co-operative; The Indian Dairy man, Vol.I. 38 August P. 404.

k) Singh M, Verma D.S. and Yadava S.P. (1985), Analysis of Operational Efficiency structure of U.P. milk cooperatives in Indian co-operative Review, Vol XXII (4) August P. 397.

1) Kumar, V., Wankhede, K. G., \&Gena, H. C. (2015). Role of Cooperatives in Improving Livelihood of Farmers on Sustainable Basis. American Journal of Educational Research, 3(10), 1258-1266.

m) Varaprasad, R., \& Rao, K. V. (2014). Consumer Perception and Satisfaction with Branded Milk and Milk Products. International Journal of Applied Services Marketing Perspectives, 3(2), 1023. 